I. Eggs were stored in an atmosphere containing o or 2 p. Ioo of carbon dioxide. Without $\mathrm{CO}_{2}$, the thinning of thick egg white was accompanied by a decrease of both total ovomucin and NANA content of this precipitate (fig. I, 2) while its $\mathrm{pH}$ value was enhanced (table $\mathrm{I}$ ). The decrease of total ovomucin content excepted, all these alterations were suppressed by 2 p. Iоo of $\mathrm{CO}_{2}$ in the storage atmosphere.

2. Eggs produced by hens made acidotic by a diet containing 3 p. Ioo of $\mathrm{NH}_{4} \mathrm{Cl}$ were also studied. Increase in the height of the thick white was accompanied by a small, non significant increase in precipitable ovomucin complex without any variation of its NANA content (table 2).

3. These results are discussed in relation to the hypothesis of RoBInson (1972) which supposed that NANA can participate in the gel structure of the thick white. It is proposed that, during egg storage, $\mathrm{CO}_{2}$ acts through a protection of the $\beta$-components of ovomucin (carbohydrate rich fraction).

4. Attention is called on the specific effect of divalent cations in the control of the height of the thick egg white gel according to the previous hypothesis of SAUveUR (I970 and 1971).

\title{
THE EFFECT OF IN VITRO EGG PLUMPING ON EGg WHITE PHYSICO-CHEMICAL PROPERTIES
}

\author{
B. SAUVEUR \\ avec la collaboration technique de $\mathrm{M}^{\mathrm{me}}$ Huguette Antorne \\ Station de Recherches avicoles, \\ Centre de Recherches de Tours, I. N. R. A., \\ Nouzilly, 37380 Monnaie
}

The purpose of this investigation was to study the possibilities of modifying the physicochemical properties of the egg-white by plumping the uterine eggs in artificial solutions. Soft shelled eggs were expelled out of uterus six hours after the former oviposition and immersed during four hours in either distilled water, or solutions of $\mathrm{NaCl}, \mathrm{CaCl}_{2}, \mathrm{MgCl}$, and glucose at $300 \mathrm{mOsm}$ (ten eggs in each treatment).

The hourly weight gain of the egg and water content of the egg-white after four hours are reported in table $\mathrm{I}$. Whatever the nature of the solution, the rate of plumping was higher during the first two hours than during the two following. The final egg-white water content was as follows : Glucose $<\mathrm{MgCl}_{2}<\mathrm{CaCl}_{2}<\mathrm{NaCl}<\mathrm{H}_{2} \mathrm{O}$. This result is in good agreement with general laws of water imbibing power of polyelectrolytes; it confirms that divalent cations ( $\mathrm{Mg}$ and $\mathrm{Ca}$ ) are bound more extensively than $\mathrm{Na}$ to egg-white organic matter.

Table 2 refers to some properties of egg-white, estimated after the in vitro hydratation. The height of thick white (first column) was increased by $\mathrm{CaCl}_{2}, \mathrm{MgCl}_{2}$ or glucose, relatively to $\mathrm{H}_{2} \mathrm{O}$ or $\mathrm{NaCl}$. So it was quite possible to modify this very important character of egg-white quality, without any alteration of protein content. It appeared that high values of Haugh units required a great cohesion of peptidic chains (obtainable by high levels of $\mathrm{Ca}$ and $\mathrm{Mg}$ ) and, consequently, a low water content of the thick white.

The reported values of viscosity have to be considered with caution because they were 
obtained with an ordinary Ostwald viscometer after blending of egg-white at high speed. Anyhow, concentrations of proteins and minerals in egg-white seemed to be too high to allow a simple application of general laws governing the viscosity of glycoproteins.

The study of egg-white osmotic pressure and mineral content (tables 3 and 4 ) showed that, with $\mathrm{NaCl}$ treatment at least, the egg-white plumping occurred according to the Donnan equilibrium. The increase of osmotic pressure $(320 \mathrm{mOsm})$ observed with $\mathrm{NaCl}$ relatively to $\mathrm{CaCl}_{2}$ or $\mathbf{M g C l}_{\mathbf{2}}$ (30r mosm) was a supplementary evidence for the binding of divalent cations to organic molecules.

\title{
VI. - Economies
}

\section{ECONOMIC INVESTIGATIONS OF THE TECHNICAL INSTITUTE FOR AVICULTURE}

\author{
J.-L. IRONDE \\ Division économique, I.T.A.V.I., \\ 28, Rue du Rocher, \\ 75008 Paris
}

Forecasting of the future necessitates a thorough analysis of the evolution mechanisms. The task of the I. T. A. V. I. is therefore to examine closely the various elements necessary to establish the synthesis of a global phenomenon. With this end in view, the Division of Economics of I. T. A. V. I. carries out series of investigations among poultry producers, and the results are published in various documents. The main object of this work is to study the production cost and cost prices.

At the beginning, the investigations were empiric, but as the work proceeded, the data obtained enabled us to realize the first analysis of the cost-price of the egg production. The conception, sampling, collection of informations, supervision of questionnaires, have needed the contribution of several engineers and technicians.

At present, the investigations of the I. T. A. V. I. (permanent or conjunctural) deal with the production of broilers and other birds. New methods are used, such as " panels " allowing determinations of the continuous development of techniques, production costs and cost-prices.

As regards the egg production, it has been possible to determine the most fitted rearing and breeding conditions and to reduce the cost-price, in particular by defining the optimum size for the production units.

In the field of broiler production, the "panels " have been used to define accurately different important factors affecting the cost-price.

However, the work of the I. T. A. V. I. is not only to gather informations but, above all, to establish a permanent dialogue with the whole profession, allowing, for instance, important decisions to be taken such as changes in a given production system according to the general economic situation. 